\title{
Democratization of Brazilian Health Councils: The Paradox of Bringing the Other Side into the Tent
}

\author{
VERA SCHATTAN P. COELHO
}

\begin{abstract}
Contemporary discussions of 'democratic innovation experiences' have evolved into a heated debate about how effective these 'new spaces' are in including ordinary citizens, particularly those traditionally marginalized and excluded. This article focuses on the Brazilian experience with Health Councils and begins by discussing the conditions that have been pointed out by previous studies as favouring the inclusion of these groups in these 'new spaces'. On the basis of these studies, one question that remains is about the democratic legitimacy of these experiences, as it seems that there is a bias towards the inclusion of those that already have political ties with the traditional political system. The local Health Councils in 31 subprefeituras (new administrative subdivisions) of the city of São Paulo were researched and a continuum was observed: ranging from a small number of one or two sectors that have historical ties with political parties included in the council to a far more diversified composition, including up to seven sectors with autonomous representatives and various types of association. Using these results as their starting-point, the analyses conclude with a discussion of the relative significance of the factors previously identified as central in establishing the democratic legitimacy of these 'new democratic spaces'.
\end{abstract}

\section{Introduction}

The idea of making democracy more inclusive is not a new one. It is present, for instance, in the advocacy of proportional representation as a system that creates more opportunities than majority rule for the representation of minorities, as well as in the effort to multiply and strengthen spaces for deliberation within parliaments. It was after the mid-1970s, however, that participation and deliberation in 'new spaces' created in

This article presents the results of the 'Participation and Social Inclusion in Brazil' project, carried out by the Centro Brasileiro de Analise e Planejamento (Brazilian Centre for Analysis and Planning: CEBRAP) with the support of the Development Research Centre on Citizenship, Participation and Accountability, Institute of Development Studies, University of Sussex. A previous version of this work also appeared in the Annual Report of the Citizenship DRC. I would like to thank the Advisors on Social Participation of the Health Secretariat of the Municipal Authority of São Paulo, the Municipal Council, the Health Coordination Team and Management Councils of the subprefeituras for their support and interviews, as well as John Gaventa, Argelina Figueiredo, Andrea Cornwall, Alex Shankland, Joanna Wheeler, Marian Barnes, Marcus Melo, G. Baiocchi, David Kahane, Adrian Gurza Lavalle, Simeen Mahmud and the 'Spaces for Change' research group' for their valuable comments and suggestions, and José Veríssimo, Tiago Borges, Carolina Galvanezzi and Nílian da Silva for their valuable contributions in collecting and organizing research data. 
the state or public sphere at local, national or international levels began to be advocated as key ways to make democratic systems more inclusive (Coelho and Nobre, 2004). These 'new spaces' are based on the idea that the inability of public policies to promote substantial changes in the status quo results in large part from the non-inclusion of ordinary citizens in the decision processes through which such policies are defined. As political institutions become capable of including ordinary citizens in policymaking at the local and national levels, policies should become more responsive to their needs. After all, who would know better the problems that affect the population or the quality of services than the population itself? The principles of participation and decentralization are quite attractive, and are at the basis of the ongoing effort to democratize democracy around the world.

This article focuses on management councils that, at least in terms of scale, are currently the most important participatory mechanism in Brazil. Over 28,000 of these councils have been established for health policy, education, the environment and other issues. They are organized at all levels of government, from local to federal, and they provide forums in which citizens join service providers and the government in defining public policies and overseeing their implementation. In order to better understand the nature of the participation being fostered in these fora, a broad survey was conducted with the 31 Local Health Councils (LHCs) in the city of São Paulo to answer two main questions. First, is there evidence that a plural representation of civil society is underway, or is representation monopolized by the groups that already have political ties with public managers? Second, assuming that it is possible to recognize distinct patterns i.e. a larger or narrower range of associations included - can we relate these, as suggested by the literature, to certain characteristics of management, institutional design or associational life?

In the next section I review the literature that discusses the democratic potential of these 'new spaces'. In the following section I review the legal and political context of Municipal Health Councils (MHCs) and LHCs. I then present the associative profile of the participants of the 31 LHCs in the city of São Paulo and discuss the importance of political, institutional and social variables in explaining the variation found in the number of associations present in these councils. Next, I discuss how the strategies adopted by civil society and committed public managers play an important part in accounting for the degree of inclusiveness, as they may orient their procedural choices in ways that can significantly expand or constrain the inclusion of non-allies in these 'new spaces'. Finally, I discuss the lessons that can be learnt about how to build more inclusive participatory institutions.

\section{Citizen participation in Brazil}

Given the constitutional reform and political innovations it has witnessed in the last decade, Brazil has been seen as one of the world's most important laboratories of democratic innovation (Gaventa, 2004). The 1988 Brazilian Constitution, which established the formal transition to democracy, sanctioned the decentralization of policymaking and established mechanisms for citizens to participate in the formulation, management and monitoring of social policies (see Chapters II, IV and VII). Hundreds of thousands of interest groups worked throughout the country as the Constitution was being drafted and collected half a million signatures to demand the creation of participatory democratic mechanisms.

This legal foundation promoted the development of an extensive institutional framework for participation by citizens, which included management councils, public hearings, conferences, participatory budgeting and deliberative mechanisms within regulatory agencies. Of the plethora of participatory mechanisms in Brazil, participatory budgeting and management councils gained the greatest momentum in the 1990s. These 
two participatory mechanisms are linked to the executive branch and emphasize transparency, local control and the redistribution of resources to underserved areas (Coelho et al., 2005).

Previous research, however, has raised questions about how effective these councils are at promoting citizen participation. In this view, their democratic promise has been compromised by a lingering authoritarian political culture in the Brazilian state, a fragile associational life, and resistance from both society and state actors (ABRASCO, 1993; Carvalho, 1995; Andrade, 1998; Carneiro, 2002). In this context, even when management councils are implemented, the poorest citizens remain excluded and continue to lack sufficient resources to articulate their demands, while the costs of participation continue to be lower for those with more resources.

These findings strengthen claims that participatory mechanisms are poor tools to achieve political equality. It has been argued that inequalities pervading the sociopolitical structure - inequalities like access to information, influence over government, and organizational possibilities - entail asymmetries and restrain political participation, which reinforces inequality and so deepens the representation deficit of disadvantaged actors (citizens with low income, low education and low information access, for instance) (Pozzoni, 2002). Participatory processes would therefore generate new forms of exclusion and entail risks that include 'the control of decision bodies by more active and established groups' (Jacobi, 2000: 107). ${ }^{1}$

An increasing number of studies suggest the opposite: that under certain circumstances these fora might not only include the most disadvantaged segments of society but play a meaningful role in defining public policies (Abers, 2001; Baiocchi, 2001; Avritzer and Navarro, 2003; Marquetti, 2003; Wampler and Avritzer, 2004). Overall, such analyses stress three determining factors. First, they suggest that certain conditions must be overcome before groups in civil society can effectively mobilize and organize. Second, the success of such fora depends on public authorities' commitment to the participatory project. Third, institutional design is crucial to their success.

With respect to the first factor, Gurza Lavalle et al. (2004) found evidence that new participatory spaces might favour the representation of excluded social groups. According to their study, rich and poor actors in civil society have equal propensities to participate, and the design of the new spaces may favour political initiatives by traditionally under-represented social groups. They argue that 'the participation promoted by the wave of institutional experimentation and innovation in recent years is not merely an exercise of common citizens' political involvement in the design of public policies, but rather includes a diverse range of collective actors' (Gurza Lavalle et al., 2004: 356). This is a crucial point, as collective actors have tendencies and modes of participation that are distinct from those of individual actors, because the former have organizational resources that lower participation costs.

Data from a survey on 'Collective Action in São Paulo' also indicate a wide variation in associative behaviour within the subprefeituras (new administrative subdivisions), demonstrating that agents from a broad spectrum of civil society, including residents of the poorest areas of the city, are making a strategic investment in popular organizations as a way of gaining voice in the political process that decides issues affecting their lives (Avritzer et al., 2004). The term 'popular organizations' appears, in the survey, to cover both neighbourhood associations and those linked to housing, health and education issues, representing 5\% of the city's population, and implying that some 500,000 individuals are affiliated to popular organizations. Half of this population earns less than twice the minimum wage and has completed basic education only (dropping out of school at age fourteen), while $60 \%$ are women. These data point in the same direction as the data gathered by the project 'Participation and Social Inclusion in Brazil' (Coelho,

1 Observers of participation in political campaigns and voting behaviour in richer countries have shown the powerful effect of income on participation (Verba et al., 1995). 
2004); an important percentage of those who do participate in Health Councils in São Paulo have low levels of education and income. In other words, the poor are participating. Of the other 2 million inhabitants that have associative links, $51 \%$ are concentrated in religious organizations, and it should be noted that an important set of these associations is also active with regard to community, housing and health issues. Yet another aspect underscored by Abers (2001) in her study of Porto Alegre's Participatory Budget is that people's belief that participation will bring them tangible benefits has a mobilizing effect, which balances organizational inequalities between participating groups over time.

As for the second factor - public authorities' commitment to the participatory project - Abers (2001), Baiocchi (2001) and Wampler and Avritzer (2004) maintain that a key factor in the success of the participatory budget is investment by public authorities and local public institutions in the 'demonstration effect'. Public policy fora do not attract participants where the relationship of those bodies to people's everyday lives is not clear. However, in the participatory budgeting process studied by Abers, the city government had to make it clear to participants why their presence in assemblies would benefit them, and afterwards it had to strictly fulfil its promises. Abers suggests that a good participatory policy process does not reduce government involvement in decision-making. On the contrary, the state's active commitment is crucial to citizen participation.

Finally, for the third factor mentioned, Cifuentes (2002) and Fung (2003) among others argue that the ability of participatory fora to contribute to defining an agenda that expresses the interests of the poorest might be favoured by the use of institutional and procedural mechanisms that foster both the inclusion of participants with less technical expertise and fewer communication resources and their ability to take stands. These authors suggest the use of structural incentives, ${ }^{2}$ participatory methodologies and deliberative approaches as ways to improve inclusiveness as well as the quality of endogenous processes of preference formation.

This brief overview shows that there are political and institutional processes that have contributed to changing the profile and scope of civil society's participation in public policies. Nevertheless, while many studies show that there has indeed been an increase in participation, they also suggest that it has been allowed by networks with strong partisan ties and loyalties (Coelho, 2004; Gurza Lavalle et al., 2004; Hayes, 2004; Cornwall, 2006). These studies point out that participants already have ties with public officials as political allies or service providers. It seems that sometimes public officials need to assure civil society's participation and call upon their allies to play this role, and sometimes providers wish to guarantee their contracts with the municipality and use their vote in participatory arenas to bargain. The process might then represent a new mechanism for the exclusion of those outside such sociopolitical networks.

In this context important questions about the democratic legitimacy of the processes currently underway remain: have they been guaranteeing the inclusion of a plurality of civil society's segments? After all, when do public managers or civil society's mobilized segments bring their competitors into politics? Under what conditions are groups that do not belong to the networks of those managers included? These are core questions for the debate on social participation.

Data collected during this research found a diverse profile of participation in councils, ranging from councils including only one or two categories of associations that have ties with existing political bodies, to councils with a far more diversified composition. The question that remains and that will be tackled in the remaining sections is: how do we explain these differences? 


\section{Health Councils in São Paulo}

\section{The legal context}

The 1988 Constitution defined health as a right of all citizens and a responsibility of the state, and established the Unified Health System (SUS) - the Brazilian public health system - based on the principles of universality and equity of healthcare provision. The SUS introduced the notion of accountability (social control) and popular participation. Health Councils emerged within the legal framework as the institutions responsible for enabling citizen participation in health governance. They were set up from local to state and federal levels, being responsible not only for taking government projects to the population, but also for conveying suggestions from the population to the various levels of government.

Health Councils are permanent collective bodies that consist of citizens, health professionals, public officials and health service providers. There are currently more than 5,500 Health Councils involving almost 100,000 citizens and a vast number of associations. Health Councils are political fora in which participants discuss issues and may make alliances to help the Health Secretariat plan and define priorities and policies. The Basic Operational Norms regulating the SUS stipulate that the number of representatives of civil society (citizens) must be equal to that of service providers, health professionals and government institutions taken together.

The strength of the MHCs largely derives from the law granting them veto power over the plans and accounts of the Health Secretariat. If the council rejects the plan and budget that the Health Secretariat is required to present annually, the Health Ministry, which manages $55 \%$ of the public health budget, does not transfer funds. MHCs such as the one in São Paulo are of particular importance in health governance because one of the principles of the SUS was decentralization of the health system. Through the process of decentralization, municipal governments took on greater responsibility for both health planning and service provision. This process turned the municipality into a key political space for the definition of health policies, and MHCs into an important arena for participation in policy making (Coelho et al., 2005). Local Health Councils (LHCs) have similar functions and were created in a number of Brazilian metropoli at the subprefeituras' level. They have similar functions to those of the MHC but no veto power, since they lack a constitutional mandate.

\section{Local Health Councils}

The city of São Paulo, which has a population of some 10.5 million, ${ }^{3}$ is conspicuous for its sharp social inequality and unequal access to public services (CEM, 2002). Much as in other Latin American mega-cities, the poorest areas are located on the outskirts. Wealthier areas, concentrated in the city centre, receive more public healthcare services and have the largest number of hospital admissions. Poorer areas have the lowest levels of access to healthcare (Coelho and Pedroso, 2002). To counter these trends the Workers Party (PT) that governed the city from 2000 until 2004 prioritized decentralization and citizen participation. Shortly after rising to power, the PT administration subdivided the city into 31 political administrative regions, the so-called subprefeituras. ${ }^{4}$ The population of these subprefeituras varies from 134,204 to 630,202, and their Intra Municipal Human Development Index (IMHDI) ranges from 0.65, which indicates poor

3 This figure refers to the municipality of São Paulo. The Greater São Paulo area has a population of 17.6 million.

4 In 2000, the city was divided into 41 health districts corresponding to the 41 district councils. In mid2003, the city was divided into 31 subprefeituras, with the district councils absorbed by these and being renamed local councils. The term 'local councils' will be used to refer to both periods. 
educational, income and health conditions, up to 0.91 , which indicates much better conditions (see Table 1 column 1$).^{5}$

In each subprefeitura, an LHC as well as a large number of councils located at the health facilities were created. They were set up over two years, involving the mobilization of over 2,500 people to participate in at least one monthly meeting - a significant number, especially considering the limited financial resources available to support the process. The Local Health Councils of the subprefeituras consist of 24 effective and 24 substitute councillors, half of whom represent civil society and the other half the government, service providers and health workers. The government is represented by officials appointed by the Health Secretariat, by the sub-municipal administrator or by the health coordinator of the sub-municipal authority. In the case of users and service providers, the movements, associations and sectors choose their candidates and an open meeting is held in which mandates are formalized. Elections are publicized and health system technicians monitor the appointment process. The MHC of São Paulo legally includes representation from popular health movements, social movements, unions and associations of the disabled and people with health disorders. LHC rules only specify that $25 \%$ represent health workers, $25 \%$ represent public and private service providers and $50 \%$ represent civil society.

Despite the importance of understanding how these councils work and whether they have an impact on health policy (Gohn, 2001; Côrtes, 2002; Tatagiba, 2002; Coelho, 2004; Fuks et al., 2004), this article focuses on just one feature: the composition of LHCs, as their democratic potential depends on their capacity to include a diverse and non-biased range of civil society segments.

\section{Selection of councillors and the composition of Local Health Councils}

In 2001 and 2002, Eduardo Jorge, a historical leader of the 'Sanitarian Movement'6 which has existed for over 30 years and mobilizes health professionals around the SUS, especially those in public health — was the Municipal Health Secretary and was responsible for promoting a swift decentralization of municipal health policy. In that process, the first LHCs were created.

In 2001, the Health Secretariat ordered the subprefeituras to organize their LHCs within a very short time and with few resources. The electoral processes during that period in four subprefeituras in east São Paulo have been previously reported. In those subprefeituras, recruitment for the councils was carried out by public managers within a network of associations with which they had some previous relationship. Other organized groups without the same ties remained apart from the process. In the interviews we conducted with 22 leaders of associations that work with health-related issues in the areas studied, but who did not take part in the council, only five were aware of their existence (Coelho and Veríssimo, 2004).

In order to see if this dynamic was repeated in subsequent elections, we conducted a survey in 2004-2005 on the composition of the 31 LHCs, on procedures for selecting councillors and on managers' adhesion to the social participation project. Our first hypothesis was that we would find a broader range of civil society segments represented

5 The IMHD varies from 0 to 1 and is calculated for each subprefeitura based on data about income and education of the head of the family gathered by the Censo and formulated by the Brazilian Institute of Geography and Statistics (IBGE) and infant mortality and longevity rates formulated by State Foundation for Data Analysis (SEADE). The higher values indicate that better conditions are present.

6 The Health Movement originated in the early 1970s in the eastern part of the city. The Movement militated for a better public health system and was supported by Christian grassroots communities, students and public health workers. 
Table 1 Characteristics of councils by subprefeituras - Municipality of São Paulo, 2003-05

\begin{tabular}{|c|c|c|c|c|c|c|}
\hline Subprefeituras & IMHDI & $\begin{array}{c}\text { No. of } \\
\text { Association } \\
\text { Categories } \\
\text { Represented }\end{array}$ & $\begin{array}{l}\text { Score for } \\
\text { Procedures } \\
\text { and } \\
\text { Contacts } \\
\end{array}$ & $\begin{array}{c}\text { Score for } \\
\text { Management } \\
\text { of } \\
\text { Participation }\end{array}$ & $\begin{array}{c}\text { Score for } \\
\text { Popular } \\
\text { Associativism }\end{array}$ & $\begin{array}{l}\text { No. of } \\
\text { Above } \\
\text { Average } \\
\text { Scores }\end{array}$ \\
\hline Jd Angela & 0.64 & 1 & 4 & 3 & 13 & 1 \\
\hline São Miguel & 0.67 & 1 & 8 & 11 & 6 & 1 \\
\hline Cidade Ademar & 0.69 & 1 & 9 & 8 & 5 & 1 \\
\hline Casa Verde & 0.73 & 1 & 8 & 9 & 9 & 1 \\
\hline Penha & 0.73 & 1 & 7 & 9 & 14 & 1 \\
\hline Campo Limpo & 0.74 & 1 & 8 & 11 & 3 & 1 \\
\hline Cidade Tiradentes & 0.67 & 2 & 4 & 10 & 5 & 0 \\
\hline Freguesia do 0 & 0.70 & 2 & 10 & 9 & 7 & 1 \\
\hline Itaquera & 0.71 & 2 & 2 & 5 & 8 & 1 \\
\hline Santo Amaro & 0.85 & 2 & 7 & 11 & 3 & 1 \\
\hline Tremembé & 0.68 & 3 & 6 & 10 & 5 & 0 \\
\hline Ermelino & 0.73 & 3 & 9 & 14 & 0 & 2 \\
\hline Jabaquara & 0.73 & 3 & 13 & 13 & 6 & 2 \\
\hline Ipiranga* & 0.76 & 3 & & & & \\
\hline Santana & 0.81 & 3 & 9 & 15 & 7 & 2 \\
\hline Parelheiros & 0.65 & 4 & 6 & 12 & 3 & 1 \\
\hline Socorro & 0.67 & 4 & 14 & 12 & 2 & 2 \\
\hline VI Maria & 0.73 & 4 & 7 & 12 & 12 & 2 \\
\hline Aricanduva & 0.76 & 4 & 15 & 15 & 1 & 2 \\
\hline Lapa & 0.85 & 4 & 6 & 11 & 6 & 1 \\
\hline Pinheiros & 0.91 & 4 & 12 & 11 & 13 & 3 \\
\hline Itaim Paulista & 0.67 & 5 & 9 & 8 & 11 & 3 \\
\hline São Mateus & 0.67 & 5 & 7 & 11 & 4 & 1 \\
\hline VI. Prudente & 0.69 & 5 & 6 & 11 & 13 & 2 \\
\hline Pirituba & 0.71 & 5 & 7 & 11 & 16 & 2 \\
\hline Guaianazes & 0.67 & 6 & 10 & 14 & 1 & 2 \\
\hline Mooca & 0.80 & 6 & 10 & 11 & 4 & 2 \\
\hline VI Mariana & 0.88 & 6 & 10 & 6 & 7 & 1 \\
\hline Perus & 0.69 & 7 & 9 & 12 & 2 & 2 \\
\hline Butantã & 0.79 & 7 & 9 & 9 & 12 & 2 \\
\hline Se & 0.84 & 7 & 9 & 10 & 13 & 2 \\
\hline Average & - & - & 8.33 & 10.46 & 7.03 & - \\
\hline
\end{tabular}

* The questionnaires for the subprefeitura of Ipiranga were not completed. This subprefeitura appears in Table 3 as we have information about the associational profile of the councillors, but was not included in the remaining analysis due to the lack of data concerning the other variables.

in councils in subprefeituras where managers were more committed to the project and where the council had made efforts to publicize the selection process. To test this hypothesis further, we decided to gather information on the different profiles of social mobilization in these subprefeituras. Data on associative behaviour was collected and 
prepared by the survey 'Collective Action in São Paulo' conducted in 2002 by Avritzer et al. Analysing these data presented difficulties, as discussed below, some of them methodological and others relating to the scope of a survey that covered the 31 subprefeituras in a city as large as São Paulo. ${ }^{7}$

The data gathered on the composition of LHCs in the 31 subprefeituras show that some include only one or two categories of association, while others include up to seven categories, including non-affiliated representatives. Councillors reported themselves as representatives of popular health movement, health units, religious associations, neighbourhood associations, Unions, civil rights groups, participatory fora, the homeless movement, the landless peasants movement (MST), community or philanthropic groups, disabled persons associations, or as non-affiliated representatives. ${ }^{8}$

Table 1 (column 2) shows that in 16 of the 31 subprefeituras more than three categories are represented. At least three of these categories - community groups, disabled associations and non-affiliated representatives - have no traditional association with the PT. Twelve subprefeituras included non-affiliated representatives, and their inclusion is not strongly associated with IMHDI rank. It seems reasonable to argue, then, that the LHCs are opening spaces for representation of the range of associations that make up civil society in the city, and that they have real potential as a space where different groups can negotiate projects and proposals concerning public health.

Nevertheless, the survey also found that 29 of the 31 subprefeituras concentrated recruitment in health facilities. Six subprefeituras included only these. In eastern and southern regions this way of organizing representation is strongly associated with the Popular Health Movement (PHM), which has been highly active in those regions since the 1970s and has strong ties with the PT (Bógus, 1998). Other categories historically often related to left wing parties, such as religious associations, participatory fora and the homeless movement were also more frequently represented (in 15, 7 and 10 subprefeituras respectively). Of the 15 subprefeituras representing three categories or less, 11 have a strong presence of associations with ties to the PT.

\section{Design}

So does the difference in the number of sectors represented relate to how elections were organized?

In order to identify differences between electoral processes that occurred in the various sub-municipal authorities, we determined whether a database of associations and movements in the region had been organized, what means were used to publicize the elections (newspapers, radio, internet, mail campaigns), whether candidatures were granted both to individuals and to organizations, and whether documentation on the entire election process was available. We also attempted to determine whether or not there were systematic contacts between the council, civil society, the health system and the political system, since we believe that by improving those contacts councils tend to become better known, increasing the likelihood that elections become more competitive.

7 One of the obstacles faced was that there is no census information available on the formal and informal organizational/associational universe in São Paulo. That makes it difficult to assess whether fewer segments in a Council reflect the subprefeituras' organizational/associational make-up, or the Councils' inability to include sectors present in the subprefeitura and willing to take part in defining the health policy. We have no means of reconstituting the associational universe of the subprefeituras, but, as will be seen in the analysis presented next, there is evidence to support the idea that those councils that include a higher number of civil society sectors are not just translating the presence of a higher number of sectors in a given subprefeitura. We acknowledge, however, the risks entailed by such a stance and the need for a future complementation of available information in order to make our analysis more rigorous.

8 See Appendix. 
Data collected showed that the 2003 and 2004 elections were organized in very different fashions in the distinct subprefeituras. In some of them, civil society was in charge of the electoral process and in others it was limited to organizations already known to public managers. There were also cases of active work by those managers in order to contact and involve a wide range of organizations and users. Table 1, column 3 presents information relating to the process of choosing councillors who represent civil society and the intensity of relationships established between the council, civil society and the political and health systems. On the basis of responses to our questions we calculated values (between 1 and 15) for these relationships and procedures: the higher the value, the more relationships that council has and the more inclusive are its adopted procedures. We did not find, however, any significant statistical association between the spectrum of associations represented and the process of choosing councillors or the intensity of relationships established by the council.

\section{Public managers' commitment}

As for public managers, we expected that those most committed to the project of social participation would invest in the construction of effective councils, which in turn should contribute to raising society's interest in participating. That is, we expected that the higher a managers' commitment, the more segments would be represented in councils. This commitment was inferred from the replies to questions on the existence of a budget provision; the type of information submitted and the way in which it was made available to councils; the regularity of submission of such information; the presence of the health coordinator within the council; and councillors' ease of access to the authorities and the information they requested..$^{9}$ On the basis of responses we calculated values (between 1 and 15) that are presented in Table 1 column 4: the higher the value, the greater the commitment shown by the public sector manager to local social participation. We did not find, however, any significant statistical association between the spectrum of categories of civil society represented in the councils and the commitment of public officials to participation as a political project.

\section{Collective action/popular organizations}

These results suggest the need to revisit the stance of those who aim to explain variation in participation by the degree of civil society organization. According to that argument, given that civil organizations are unevenly distributed over the city, it should be possible to explain the variation in number of categories of organizations represented in the councils by their presence in the distinct subprefeituras. Associative behaviour was evaluated on the basis of the statistical data gathered by the survey on 'Collective Action in São Paulo' and refers to the number of individuals from a sample who declared they had taken part in activities linked to popular organizations. Column 5 presents the weighted frequency of participation in activities linked to popular organizations by those who replied. However, we have not found any significant statistical association between the spectrum of segments represented in the councils and the degree of participation in popular organizations in the subprefeituras.

\section{Simultaneous presence in a given subprefeitura of the researched variables}

These findings suggest that the inclusion of a wider spectrum of participants cannot be explained only by design (the publicizing of the elections), political variables (the commitment of public officials) or associative variables (the percentage of participants in civil associations). So once again, how do we explain the differences in the range of

9 The existence of a budget provision for the LHC, the presence of managers that regularly report information directly to the councillors about programs, budgets and plans and that also answer to the councillors' requirements are expected to contribute to a good performance of the LHC. 
Table 2 Number of sectors present in Local Health Councils and characteristics of management of social participation, of associativism and of the selection procedures ? São Paulo, 30 subprefeituras, 2003-05

Number of Sectors One Favourable Condition* (+) Two or Three Favourable Conditions* (+)

\begin{tabular}{llc}
\hline Up to 3 & 11 subprefeituras & 3 subprefeituras \\
\hline More than 3 & 4 subprefeituras & 12 subprefeituras \\
\hline
\end{tabular}

${ }^{*}$ Favourable conditions are understood as the presence of committed managers, a high degree of associationalism and inclusive procedures. Favourable conditions can range from one, when only one of these conditions is present, to three, when all three are present.

associations represented on different councils? We next tried an alternative approach aimed at assessing the role of the simultaneous presence of the variables we had analysed. Using the available data, we assigned the councils one point for each variable that was above average (Table 2.1 column 6). Adding these points we expected that higher values would predict a wider spectrum of sectors represented in the council. Based on that analysis, we found a strong pattern. ${ }^{10}$ This positive association is summarized in Table 2.

Our analysis suggests that none of the three variables analysed by itself explains the breadth of segments represented in the councils, but the simultaneous presence of these variables in a given sub-municipal authority does favour diversity. ${ }^{11}$

These data are worth closer inspection. The simultaneous presence of the variables in question is associated not only with a greater range of associations, but also with the presence of non-affiliated representatives. ${ }^{12}$ While we have no means of reconstituting the organizational universe of the subprefeituras, we know that there are "non-affiliated citizens' in all of them and that those autonomous citizens are indeed more systematically present in the subprefeituras' councils where the variables in question also have a stronger presence. Given that those councils also include a higher number of civil society sectors, we have good reasons to believe that this is due to a process of interaction between public managers and civil society sectors that seek to influence health policy, and it is not merely a result of a higher number of sectors in a given subprefeitura.

\section{Civil society, managers and procedures in the subprefeituras}

We are then led to another question: what kind of interaction between public managers, social associations and procedures favours the inclusion of a wider spectrum of civil society segments in the councils? In order to outline an answer we used data gathered in qualitative interviews carried out with public officials, health managers and councillors.

To understand the context in which these councils were set up, we have to bear in mind that decentralization creates a new field for disputes over resources between and within subprefeituras. In a government that has social participation as one of its mottoes, those that can argue that they count on the support and endorsement of civil society will be in a better position to negotiate their demands. In that context, it comes as no surprise

10 Pearson Correlation $=0.531^{* *}$. A correlation of $0.431^{*}$ also appears for the simultaneous presence of committed managers and inclusive procedures.

11 However, we found no association between the simultaneous presence of those variables and the HDI-M of subprefeituras

12 Pearson Correlation $=0.473^{* *}$ 
that a relevant percentage of managers have dedicated their efforts to the project of organizing the councils. ${ }^{13}$

To put this project in place, managers established the councils based on a variety of alliances and using quite different strategies. While some chose the Health Movement as their prime ally, others sought a wider support network, which included both conservative and progressive movements and associations, as well as autonomous representatives. In the first case, the manager-movement alliance seems related to a more incipient institutionalization of procedures for choosing representatives and to the predominance of the Health Movement presence. In the second case, the managersociety alliance was possible, to a large extent, through active work by the health coordination team towards mobilizing and publicizing the council among a broader public.

Protagonists in the first group are the managers who report a life history strongly entangled with that of the Health Movement - some of whom have even become managers based on their participation in popular movements and organizations or in the Health Movement itself. In those cases, managers and leaders of the movement reported a strong common identity. They share a 'history of struggle' and a common 'political project' rooted in the social movement history that gave birth to part of the PT. That identity explains the delegation of the organization of electoral processes to the movement and the justification given for that delegation. It is a strategy to preserve 'civil society's autonomy', as well as the acknowledgement of that group as the one most qualified to organize the process (Galvanezzi, 2004). Therefore, organizing the selection of councillors becomes itself less institutionalized thus guaranteeing space for the Health Movement within the council. As Hayes has properly pointed out, 'the history of the health movement in the area of São Miguel predicts their presence in the Health Council but their over-representation would appear to be related to their control of the selection process' (Hayes, 2004: 36).

In the second case, we find associations that do not have the same ability to organize popular mobilization as the Health Movement, and professionals related more to the hospital and labour union areas, as well as to public health. Those professionals moved areas and clientele due to changing guidelines and programmes of the municipal administration over the last 15 or 20 years. As a result of this history, there exists both a certain ease in establishing contact with movements and associations - since in their careers numerous partnerships were established in order to guarantee the implementation of distinct health programmes - and a constant change of neighbourhood. When facing the need to organize the council and to demonstrate that civil society endorsed their demands to both the subprefeitura and the Municipal Health Secretariat, those managers did their best to identify possible sources of support, which led to mobilization of a diverse set of segments, as well as non-affiliated representatives.

So we have one case in which managers and health movements guaranteed their political strength by restraining the process of selection of councillors to a universe of actors with close political ties. In the other case, managers - as well as movements, associations and autonomous representatives that do not have the same organization and identity as the Health Movement — defined their political strength by establishing a more fluid but also more diverse network of alliances. Those two situations do not exhaust the richness of cases or the specific conditions that characterize the distinct subprefeituras, but they allow an initial approximation of the nature of the actors, their interests, and the constraints involved in the process of organizing decentralized and participatory management in the city of São Paulo. 


\section{Final remarks}

Health Councils are part of a movement in which political actors and civil society have joined forces to institutionalize social participation in the process of formulating, implementing and monitoring public policies. Data collected show that a participation network has been created that is distributed throughout the municipality, covering both central and peripheral areas, as well as rich and poor ones. These data show that the spectrum of participants in LHCs in São Paulo is quite diverse, including social movements, disabled persons' associations, religious groups, civil rights associations, trade unions, and individuals with no associational ties. That spectrum proved to be more comprehensive in areas that simultaneously had public managers committed to participation as a political project and more transparent and inclusive procedures used to select the councillors, and where collective action was strong. It was also found that the presence of these conditions in the subprefeituras was not associated with the socioeconomic profile of the areas studied. Our findings suggest that at least the first of the conditions needed to guarantee the basis for social participation - the inclusion of a diverse spectrum of actors - was met in 16 out of 31 subprefeituras.

What has our analysis shown about how to build more inclusive participatory institutions? As discussed above, previous analyses of participatory processes, particularly of management councils such as those analysed in this article, highlighted variables that restrained the democratic potential of these 'new democratic spaces' in Brazil: the legacies of a lingering political culture and lack of social mobilization, as well as bureaucrats' resistance to power-sharing. Other analyses focusing on the participatory budget process offer more optimistic conclusions, showing how constraints on participation could be overcome with the involvement of committed public officials. More recent work in this field also points to a particular characteristic that seems to amplify the democratic potential of these spaces: the presence of a mobilized civil society. In previous work we drew attention to the central role that institutional design could play in deepening the democratic potential of these spaces, a role not being addressed in the debate. We argued that improving the process of council member selection and developing appropriate procedures to ensure the inclusion of all participants in discussions and decision-making processes were key elements of this institutional design.

The results presented in this chapter confirm the results described earlier by the more optimistic authors, in that the set of variables previously identified played an important role in explaining the diverse profile of councils established in the city. Drawing on the data presented, we argue that political authorities and civil society help to define procedures regulating the operation of these councils, and that the procedures chosen will significantly expand or restrict the spectrum of civil society involved. Nevertheless, our results go further as they show the significance of the simultaneous presence in a given subprefeitura of managers committed to the project of social participation, a wide spectrum of popular movements, civil associations and citizens that display interest in participating in the health policy, and a certain know-how about the organization of participatory institutions that leads to a more inclusive range of participants.

The remaining question is a difficult one: why, under certain conditions, do public officials and mobilized groups in civil society open the doors of the councils to a wide spectrum of participants, which may include partisans' competitors and those with antagonistic interests? As we have seen, the answer depends on the strategic choices made by managers and participants about which alliances and procedures they believe will best serve their interests and values. The democratic experience we have described allows some optimism about broadening the debate and experimenting with questions and practices of constructing more inclusive representation. It remains to be seen whether the actors involved in this process will be motivated and able to experiment in this way. The answer will be given in the sphere of politics, but as ferment around these 
'new spaces' is growing, we can speculate that the spectrum of social, state and political actors motivated to take part in the game will broaden.

Vera Schattan P. Coelho (veraspc@uol.com.br), Policy and Public Policies Team, Brazilian Centre of Analysis and Planning - CEBRAP, R. Morgado de Mateus, 615, 04015-902 São

Paulo-SP, Brazil.

\section{References}

Abers, R. (2001) Inventing local democracy: grassroots politics in Brazil. Westview, Boulder, CO.

ABRASCO (Brazilian Association of Collective Health) (1993) Relatório final da oficina: incentivo à participação popular e controle social em saúde [Final report:

Popular participation and social control in health]. Série Saúde e Movimento (Health and Movement Series), Vol. 1, Brasília, ABRASCO.

Andrade, I. (1998) Descentralização e poder municipal no Nordeste (Decentralization and municipal power in the North East). In J.A. Soares (ed.) $O$ orçamento dos municípios do Nordeste brasileiro [The municipal budget in the Brazilian North East], Paralelo15, Brasília.

Avritzer, L. and Z. Navarro (2003) A inovação democrática no Brasil: o orçamento participativo. [Democratic innovation in Brazil: the participatory budget]. Cortez, São Paulo.

Avritzer, L., M. Recamán and G. Venturi, (2004) Associativismo em São Paulo [Collective action in São Paulo]. In L. Avritzer (ed.) Participação em São Paulo [Participation in São Paulo], Unesp, São Paulo.

Baiocchi, G. (2001) Participation, activism and politics: the Porto Alegre experiment and deliberative democracy theory. Politics and Society 29.1, 43-72.

Bógus, C.M. (1998) Participação popular em saúde [Popular participation in Health]. Anna Blume, São Paulo.

Carneiro, C.B.L. (2002) Conselhos: uma reflexão sobre os condicionantes de sua atuação e os desafios de sua efetivação [Councils: challenges for their implementaion]. Informativo CEPAM 1.3 (March), 62-70 Fundação Prefeito Faria Lima, São Paulo.

Carvalho, I.A. (1995) Conselhos de saúde no Brasil [Health Councils in Brazil]. ENSP/ FIOCRUZ, Série Estudos, Política,
Planejamento e Gestao em Saúde 3, 5-41, Ibam/Fase, Rio de Janeiro.

Cifuentes, M. (2002) Political legitimacy of deliberative institutions. Unpublished MSc thesis, Institute of Development Studies, University of Sussex.

Centre of Metropolis Studies (CEM) (2002)

Dossiê espaço e política na metrópole

[Dossier space and politics in the metropolis]. Novos Estudos 64 (November), Editora Brasileira de Ciências, São Paulo.

Coelho, V.S. (2004) Conselhos de saúde enquanto instituições políticas: o que está faltando? [Health councils as political institutions: what is lacking?]. In V.S. Coelho and M. Nobre (eds.), Participação e deliberação: teoria democrática e experiências institucionais no Brasil contemporâneo [Participation and deliberation: democratic theory and institutional experiences in contemporary Brazil], 34 Letras, São Paulo.

Coelho, V.S. and M. Nobre (eds.) (2004) Participação e deliberação: teoria democrática e experiências institucionais no Brasil contemporâneo [Participation and deliberation: democratic theory and institutional experiences in contemporary Brazil]. 34 Letras, São Paulo.

Coelho, V.S. and M. Pedroso (2002)

Distribuição de serviços públicos de saúde no município de São Paulo [Distribution of public health services in the municipality of São Paulo]. Novos Estudos 64

(November), Editora Brasileira de Ciências, São Paulo.

Coelho, V.S., B. Pozzoni and M. Cifuentes (2005) Participation and public policies in Brazil. In J. Gastil and P. Levine (eds.), The deliberative democracy handbook, Jossey Bass, San Francisco.

Coelho, V.S. and J. Veríssimo (2004)

Considerações sobre o processo de escolha dos representantes da sociedade civil nos conselhos de saúde em São Paulo [Considerations relating to the process of 
choosing councillors in São Paulo's local Health Councils]. In L. Avritzer (ed.), A Participação em São Paulo [Participation in São Paulo], Unesp, São Paulo.

Cornwall, A. (2006) Negotiating participation in a Brazilian Municipal Health Council. In A. Cornwall and V.S. Coelho (eds.), Spaces for change: the politics of participation in new democratic arenas, Zed Books, London.

Côrtes, S. (2002) Viabilizando a participação em conselhos de política pública municipais: arcabouço institucional, organização do movimento popular e policy communities. [Participation in municipal management councils: institutions, collective action and policy communities]. Paper presented at XXV Annual Meeting of ANPOCS, Caxambu.

Fuks, M., R.M. Perissinoto and N.R. Souza (2004) Democracia e participação: os conselhos gestores do Paraná [Democracy and participation: management councils in Paraná]. Ed. UFPR, Curitiba.

Fung, A. (2003) Recipes for public spheres: eight institutional design choices and their consequences. Journal of Political Philosophy 11, 1-30.

Galvanezzi, C. (2004) A representação popular nos conselhos de saúde [Popular representation in Health Councils]. Research report, Fapesp, São Paulo.

Gaventa, J. (2004) Prefácio [Introduction]. In V.S. Coelho and M. Nobre (eds.), Participação e Deliberação: teoria democrática e experiências institucionais no Brasil contemporâneo [Participation and deliberation: democratic theory and institutional experiences in contemporary Brazil], 34 Letras, São Paulo.

Gohn, M.G. (2001) Conselhos Gestores e Participação Sóciopolítica [Management councils and socio-political participation]. Cortez, São Paulo.

Gurza Lavalle, A., P. Houtzager and A. Achrya (2004) Lugares e atores da democracia: arranjos institucionais participativos e sociedade civil em São Paulo [Places and actors of democracy]. In V. Coelho and M.
Nobre (eds.), Participação e Deliberação: teoria democrática e experiências institucionais no Brasil contemporâneo [Participation and deliberation: democratic theory and institutional experiences in contemporary Brazil], 34 Letras, São Paulo.

Hayes, L. (2004) Participation and associational activity in Brazil. Unpublished MSc thesis, Institute of Development Studies, University of Sussex.

Jacobi, P. (2000) Políticas sociais e a ampliação da cidadania [Social policies and citizenship]. Editora da FGV, São Paulo.

Marquetti, A. (2003) Democracia, equidade e eficiência [Democracy, equity and efficiency]. In L. Avritzer and Z. Navarro (eds.), A inovação democrática no Brasil: o orçamento participativo [The democratic innovation in Brazil: the participatory budget], Cortez, São Paulo.

Pozzoni, B. (2002) Citizen participation and deliberation in Brazil. Unpublished MSc thesis, Institute of Development Studies, University of Sussex.

Tatagiba, L. (2002) Os conselhos gestores e a democratização das políticas públicas no Brasil [Management Councils and the Democratization of Public Policies in Brasil]. In E. Dagnino (ed.), Sociedade civil e espaços públicos no Brasil [Civil society and public spaces in Brazil], Paz e Terra, São Paulo.

Verba, S., L.K. Schlozman and H. Brady (1995) Voice and equality: civic voluntarism in American politics. Harvard University Press, Cambridge, MA.

Wampler, B. and L. Avritzer (2004) Públicos participativos: sociedade civil e novas instituições no Brasil democrático [Participatory publics: civil society and new democratic institutions in democratic Brazil]. In V.S. Coelho and M. Nobre (eds.), Participação e deliberação: teoria democrática e experiências institucionais no Brasil contemporâneo [Participation and deliberation: democratic theory and institutional experiences in contemporary Brazil], 34 Letras, São Paulo. 


\section{Résumé}

Les discussions récentes sur les 'expériences d'innovation démocratique' se sont transformées en débats passionnés sur la capacité de ces 'nouveaux espaces' à intégrer des citoyens ordinaires, notamment ceux qui traditionnellement sont marginalisés et exclus. L'article s'intéresse à l'expérience brésilienne des Conseils de santé. D'abord il analyse les conditions qui, selon des travaux précédents, favorisent l'inclusion de ces groupes dans les 'nouveaux espaces'. D'après ces travaux, une interrogation persiste sur la légitimité démocratique de ces expériences: il existe, semble-t-il, une tendance à intégrer ceux qui jouissent déjà de liens avec le système politique traditionnel. Les Conseils de santé locaux, implantés dans 31 subprefeituras (nouvelles subdivisions administratives) de São Paulo ont été étudiés, faisant apparaître un éventail complet de cas: d'un nombre restreint de un ou deux secteurs ayant des liens historiques avec des partis politiques représentés au Conseil, jusqu'à une composition beaucoup plus diversifiée, comptant jusqu'à sept secteurs dotés de représentants autonomes et de plusieurs types d'association. Partant de ces résultats, les analyses mènent à une discussion sur l'importance relative des facteurs précédemment identifiés comme essentiels à la légitimité démocratique de ces nouveaux espaces dits démocratiques.

\section{Appendix - Categories of associations represented in the Local Health Councils of the 31 subprefeituras, São Paulo 2003-05*}

\begin{tabular}{|c|c|c|c|c|c|c|c|c|c|c|c|c|c|}
\hline $\begin{array}{l}\overline{\bar{u}} \\
\text { Ẽ } \\
\overline{0}\end{array}$ & $\begin{array}{l}\sum_{i} \\
\text { 오 }\end{array}$ & 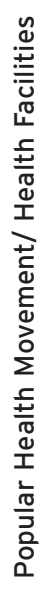 & 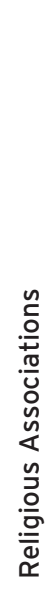 & 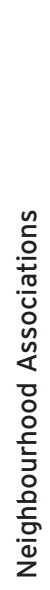 & 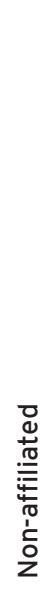 & $\begin{array}{l}\text { 음 } \\
\frac{0}{4} \\
\text { ñ } \\
\frac{0}{0} \\
\frac{0}{x} \\
\bar{z}\end{array}$ & 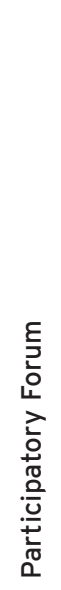 & 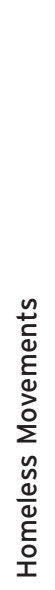 & 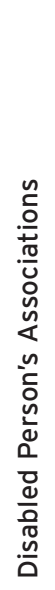 & 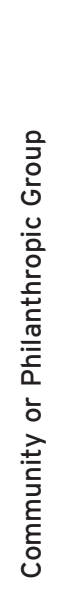 & $\begin{array}{l}E \\
E \\
\sum \\
n \\
0 \\
0 \\
0 \\
0 \\
0 \\
0 \\
0 \\
\tilde{n} \\
0 \\
\overline{0} \\
0 \\
0\end{array}$ & $\stackrel{n}{\frac{n}{c}}$ & ì \\
\hline Jd. Ângela & 0.64 & $x$ & 0 & 0 & 0 & 0 & 0 & 0 & 0 & 0 & 0 & 0 & 1 \\
\hline Parelheiros & 0.65 & $x$ & $x$ & $x$ & 0 & $x$ & 0 & 0 & 0 & 0 & 0 & 0 & 4 \\
\hline Socorro & 0.67 & $x$ & $x$ & $x$ & 0 & 0 & 0 & 0 & 0 & $x$ & 0 & 0 & 4 \\
\hline Itaim Paulista & 0.67 & $x$ & $x$ & $x$ & $x$ & $x$ & 0 & 0 & 0 & 0 & 0 & 0 & 5 \\
\hline Cidade Tiradentes & 0.67 & $x$ & 0 & 0 & 0 & $x$ & 0 & 0 & 0 & 0 & 0 & 0 & 2 \\
\hline Guaianazes & 0.67 & $x$ & $x$ & $x$ & $x$ & 0 & 0 & $x$ & 0 & 0 & $x$ & 0 & 6 \\
\hline São Mateus & 0.67 & $x$ & $x$ & $x$ & $x$ & 0 & 0 & $x$ & 0 & 0 & 0 & 0 & 5 \\
\hline São Miguel & 0.67 & $x$ & 0 & 0 & 0 & 0 & 0 & 0 & 0 & 0 & 0 & 0 & 1 \\
\hline Tremembé & 0.68 & 0 & 0 & 0 & 0 & $x$ & 0 & $x$ & 0 & $x$ & 0 & 0 & 3 \\
\hline Cidade Ademar & 0.69 & $x$ & 0 & 0 & 0 & 0 & 0 & 0 & 0 & 0 & 0 & 0 & 1 \\
\hline Perus & 0.69 & $x$ & $x$ & 0 & $x$ & $x$ & $x$ & $x$ & 0 & 0 & $x$ & 0 & 7 \\
\hline Sapopemba & 0.69 & $x$ & $x$ & 0 & 0 & $x$ & 0 & $x$ & $x$ & 0 & 0 & 0 & 5 \\
\hline
\end{tabular}




\section{Appendix Continued}

\begin{tabular}{|c|c|c|c|c|c|c|c|c|c|c|c|c|c|}
\hline $\begin{array}{l}\overline{\bar{U}} \\
\text { C } \\
\bar{O}\end{array}$ & $\begin{array}{l}\sum_{i} \\
\text { 모 }\end{array}$ & 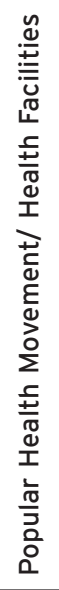 & 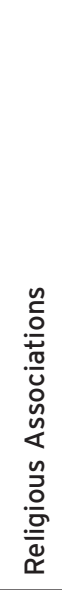 & 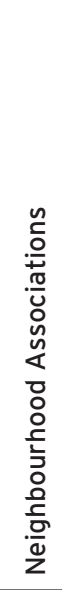 & 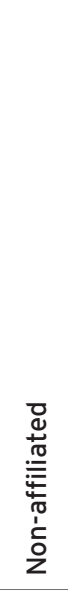 & 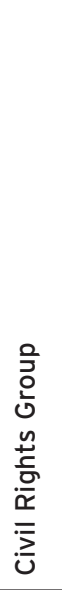 & 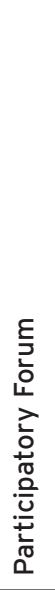 & 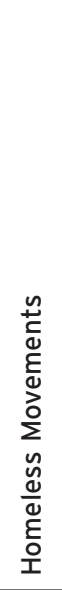 & 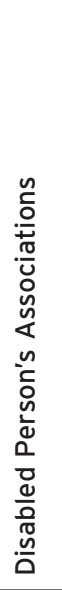 & 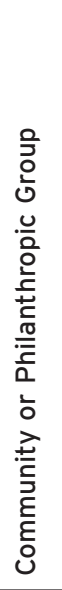 & 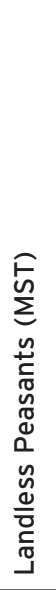 & 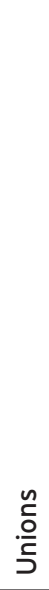 & $\dot{0}$ \\
\hline Freguesia do Ó & 0.70 & $x$ & 0 & 0 & 0 & 0 & $x$ & 0 & 0 & 0 & 0 & 0 & 2 \\
\hline Itaquera & 0.71 & $x$ & 0 & $x$ & 0 & 0 & 0 & 0 & 0 & 0 & 0 & 0 & 2 \\
\hline Pirituba & 0.71 & $x$ & $x$ & $x$ & 0 & 0 & 0 & $x$ & 0 & $x$ & 0 & 0 & 5 \\
\hline Casa Verde & 0.73 & $x$ & 0 & 0 & 0 & 0 & 0 & 0 & 0 & 0 & 0 & 0 & 1 \\
\hline Ermelino Matarazzo & 0.73 & $x$ & $x$ & 0 & 0 & $x$ & 0 & 0 & 0 & 0 & 0 & 0 & 3 \\
\hline Jabaquara & 0.73 & $x$ & $x$ & 0 & $x$ & 0 & 0 & 0 & 0 & 0 & 0 & 0 & 3 \\
\hline Penha & 0.73 & $x$ & 0 & 0 & 0 & 0 & 0 & 0 & 0 & 0 & 0 & 0 & 1 \\
\hline Vila Maria & 0.73 & $x$ & $\mathrm{x}$ & $\mathrm{x}$ & $x$ & 0 & 0 & 0 & 0 & 0 & 0 & 0 & 4 \\
\hline Campo Limpo & 0.74 & $x$ & 0 & 0 & 0 & 0 & 0 & 0 & 0 & 0 & 0 & 0 & 1 \\
\hline Aricanduva & 0.76 & $\mathrm{x}$ & $\mathrm{x}$ & $\mathrm{x}$ & 0 & 0 & 0 & 0 & 0 & $\mathrm{x}$ & 0 & 0 & 4 \\
\hline Ipiranga & 0.76 & $\mathrm{x}$ & $\mathrm{x}$ & 0 & 0 & 0 & 0 & $x$ & 0 & 0 & 0 & 0 & 3 \\
\hline Butantã & 0.79 & $\mathrm{x}$ & 0 & $\mathrm{x}$ & $\mathrm{x}$ & $\mathrm{x}$ & $\mathrm{x}$ & $\mathrm{x}$ & $x$ & 0 & 0 & 0 & 7 \\
\hline Mooca & 0.8 & $\mathrm{x}$ & $\mathrm{x}$ & 0 & $x$ & 0 & $x$ & $\mathrm{x}$ & 0 & 0 & 0 & $\mathrm{x}$ & 6 \\
\hline Santana & 0.81 & $\mathrm{x}$ & 0 & 0 & 0 & 0 & $x$ & 0 & $x$ & 0 & & 0 & 3 \\
\hline Sé & 0.84 & $x$ & 0 & $\mathrm{x}$ & $x$ & $x$ & 0 & $\mathrm{x}$ & $x$ & 0 & 0 & $x$ & 7 \\
\hline Lapa & 0.85 & $x$ & 0 & $\mathrm{x}$ & $\mathrm{x}$ & 0 & $x$ & 0 & 0 & 0 & 0 & 0 & 4 \\
\hline Sto Amaro & 0.85 & $\mathrm{x}$ & 0 & 0 & 0 & 0 & 0 & 0 & $\mathrm{x}$ & 0 & 0 & 0 & 2 \\
\hline Vila Mariana & 0.88 & $x$ & 0 & $x$ & $x$ & 0 & $x$ & 0 & $x$ & $x$ & 0 & 0 & 6 \\
\hline Pinheiros & 0.91 & 0 & $x$ & $x$ & $x$ & 0 & 0 & 0 & 0 & $x$ & 0 & 0 & 4 \\
\hline Total & & 29 & 15 & 14 & 12 & 9 & 7 & 10 & 6 & 6 & 2 & 2 & \\
\hline
\end{tabular}

*It should be noted that the table only informs whether a given category of association is present in the council and not the number of councillors representing each sector. It is worth noting that the distribution of the number of councillors among these categories of association replicates the same pattern described in the 'total' row. The majority of councillors are linked to health movements/health units and only a few are linked to MST and unions 